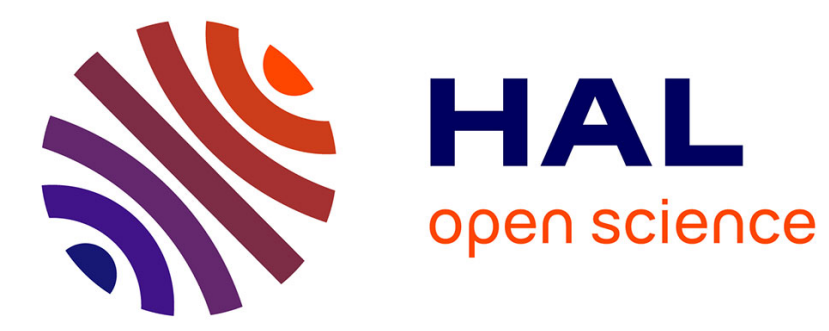

\title{
A methodological approach to analyze the territorial appropriation of high-speed rail from interactions between actions and representations of local actors
}

\author{
Valérie Facchinetti-Mannone
}

\section{> To cite this version:}

Valérie Facchinetti-Mannone. A methodological approach to analyze the territorial appropriation of high-speed rail from interactions between actions and representations of local actors. European Planning Studies, 2019, 27 (3), pp.461-482. 10.1080/09654313.2018.1562653 . hal-02066155

\section{HAL Id: hal-02066155 https://hal.science/hal-02066155}

Submitted on 4 May 2020

HAL is a multi-disciplinary open access archive for the deposit and dissemination of scientific research documents, whether they are published or not. The documents may come from teaching and research institutions in France or abroad, or from public or private research centers.
L'archive ouverte pluridisciplinaire HAL, est destinée au dépôt et à la diffusion de documents scientifiques de niveau recherche, publiés ou non, émanant des établissements d'enseignement et de recherche français ou étrangers, des laboratoires publics ou privés. 


\section{A METHOdOLOGICAL APPROACH TO ANALYZE THE TERRITORIAL APPROPRIATION OF HIGH-SPEED RAIL FROM INTERACTIONS BETWEEN ACTIONS AND REPRESENTATIONS OF LOCAL ACTORS}

Valérie Facchinetti-Mannone*

ThéMA, UMR 6049 CNRS / University of Bourgogne Franche-Comté, 4 Boulevard Gabriel 21000 Dijon, France

* corresponding author

This is a postprint version, the definitive version of this paper is :

Facchinetti-Mannone, V. (2019). A methodological approach to analyze the territorial appropriation of high-speed rail from interactions between actions and representations of local actors. European Planning Studies, 27(3), 461-482.

https://doi.org/10.1080/09654313.2018.1562653 
Abstract

Because it is difficult to separate the specific transport impact from other factors influencing economic and spatial development, the focus in research is increasingly on understanding the process by which territorial changes occur in order to explain how economic and social agents and local authorities have appropriated the new transportation system. This appropriation plays a crucial part in territorial dynamics. The diversity of economic and spatial changes produced by high-speed rail indicates the existence of multiple modes of appropriation which vary according to the location of stations, the mobilization of local stakeholders confronted with the transport operators' logic and the geographical and historical context of the infrastructure implementation.

Appropriation is defined as a dialogical identity process that must be explained to better understand the gradual and mutual adjustments between the transportation system and the territory. After specifying the issues involve in an analysis of the appropriation of high-speed rail, the article adopts an analytical framework inspired by Brunel and Roux's research work on consumer habits in order to explain how appropriation has gradually taken shape over the various stages of a high-speed line project.

Keywords: High-speed rail, territorialization process, appropriation, practices and representations, image effect.

\section{Introduction}

The complex interdependencies between transport, society and territory make it difficult to dissociate the effects of a transport infrastructure from other factors involved in economic and spatial changes (Banister and Lichfield, 1995; Plassard, 2003). Faced with the great diversity of territorial implications of high-speed rail (HSR) and in response to the difficulties in discriminating the specific transport impact from other factors influencing economic and spatial development (Adolphson and Froidh, 2017; Martinez Sanchez-Mateos and Givoni, 2012; Mohino, Loukaitou-Sideris and Urena, 2014), researchers are now focusing more on understanding the process by which territorial changes occur. Instead of inquiring into the "effects" of the new transport supply on spatial organization, it is more instructive to consider the territory as a whole in order to analyze how it has generated the infrastructure, how it has adjusted to the new conditions of accessibility and how economic and social agents and local authorities have appropriated the new transportation system through their behaviours, practices and representations (Chaplain, 1994; Delaplace, 2017; Plassard, 2003). Although it is clear that the appropriation of HSR plays a crucial part in territorial dynamics, it remains necessary to decipher its mechanisms in order to better understand territorial reconfigurations linked to the arrival of high-speed rail.

Appropriation designates either the act of taking something for oneself or the act of making something correspond to the use for which it is intended. It is defined as a dialogical identity process 
that must be explained in order to facilitate the understanding of the gradual and mutual adjustments between the transportation system and the territory. As Delaplace has pointed out (2017), appropriation is a collective construction process resulting from the multiple interactions between the agents involved in the territorialization of the HSR system. Moreover, appropriation is a long-term evolutionary process (de Vaujany, 2003) begun long before the implementation of the new infrastructure and continuing even after the trivialization of its uses. The purpose of this paper is to understand how the appropriation of HSR is constructed and how to apprehend its collective and temporal dimensions. The objectives are to show, on the one hand, how the forms of appropriation that have been developed during the genesis of the HSR project have had repercussions on strategies and practices observed later on, and to explain, on the other hand, how the interrelations between the different stakeholders' actions stimulate the territorial appropriation of high-speed rail. The focus is on examining how political and institutional strategies have acted upon other agents' practices throughout the different stages of the HSR project and how the various representations of high-speed rail have influenced the decisions and strategies adopted by the political sphere to strengthen the territorial integration of the new transportation supply.

Defining the territorial appropriation of high-speed rail from the relations between the actions and the representations of local actors requires a specific methodological approach which simultaneously takes into account these various social interactions and the temporal dimension of the process. This approach is presented in three sections. The first section outlines the issues of an analysis focused on appropriation to better understand the territorial implications of high-speed rail. The second section demonstrates the interest and relevance of transposing the analysis grid conceived by Brunel and Roux (2006) for the study of consumer habits to the process of HSR appropriation. The third section introduces a methodological framework to explain how appropriation has gradually taken shape over the various stages of a high-speed line project. Using the various data produced during the HSR project (from the early reports and studies produced during the gestation phase of the HSR project to the territorial planning documents and surveys of firms and passengers carried out after the arrival of high-speed rail), this methodological approach aims to report on the modes of HSR appropriation by jointly conducting the reconstitution of the trajectories of HSR appropriation with a semantic analysis of HSR representations. The first results ${ }^{1}$ obtained from a comparative analysis of three French territorial planning documents have highlighted the importance of taking collective representations into account to better understand the territorial appropriation of HSR.

\section{Scientific issues involved in an analysis of the appropriation of high-speed rail}

\subsection{The decisive role of the territorial appropriation of high-speed rail}

Many scholars have pointed out the difficulties inherent in discriminating the "effect" of highspeed rail from other factors involved in economic and spatial dynamics (Adolphson and Froidh, 2017; Martinez Sanchez-Mateos and Givoni, 2012; Mohino, Loukaitou-Sideris and Urena, 2014). The territorial impacts of HSR differ from one city to another (Loukaitou-Sideris, et al.2013) and vary

\footnotetext{
${ }^{1}$ The current analysis is a work in progress whose first results come from experimental studies carried out to check the validity of our methodological approach.
} 
according to the spatial scale of the analysis (Menerault, Urena and Garmendia, 2009; Garmendia, Ribalaygua, Urena, 2012; Urena, et al. 2012), the general economic context, "the physical, economic and locational circumstances and the HSR services characteristics" (Mohino, et al. 2014). Because railway stations are both nodes of transport networks and urban places (Bertolini, 1996; Bertolini and Spit, 1998), the economic and spatial effects of high-speed rail stations depend on the interactions between numerous factors. These factors include: the characteristics of HSR services (frequency, destination and type of services) and national and regional accessibility by train (Bertolini, 2008; Mohino et al., 2014; Willigers, Van Wee, 2011), the efficiency of intermodal connection (Conticelli, 2011; Facchinetti-Mannone, Carrouet, Berion, 2016; Tapiador, Burckhart and Marti-Henneberg, 2009), the location of the HSR station (Adolphson and Froidh, 2017; Givoni, 2006; De Jong, 2009; Facchinetti-Mannone, 2009; Martinez Sanchez-Mateos and Givoni, 2012) and the specificities of served areas. These specificities include the size of the city, its position in the urban hierarchy (Urena, et al. 2006 and 2012), "pre-existing economic and land market conditions" (Loukaitou-Sideris, et al. 2012), the diversity of economic activities (Bertolini, 1999) as well as supportive urban planning and economic strategies.

These strategies have a major influence on the successful integration between railway nodes and cities (Bellet, Alonso, Gutierez, 2012; Conticelli, 2011; Loukaitou-Sideris et al. 2012; Vickerman, 2015; f.i). Many scientific studies have shown that the infrastructure and the new conditions of accessibility are, ultimately, only development opportunities that territorial actors need to grasp by means of accompanying measures and appropriate development strategies. Appropriation is thus recognized as a condition in the success of the territorial development projects which started with the commissioning of a new transport infrastructure. Taking the example of the North European highspeed line, Menerault has clearly shown that the territorial changes linked with the improvement in rail accessibility closely depend on the national, regional and local modes of appropriation of the highspeed rail service (Menerault, 1996, 1997 and 2000). Several scholars (Bazin, et al. 2010; Delaplace, 2017; Feliu, 2012; Loukaitou-Sideris et al. 2012; Peters, 2009) have highlighted that the collective appropriation of the HSR service and the ability of actors to collaborate are key to the emergence of the positive "effects" of the infrastructure. In order to understand how the territory appropriates the new transport supply, several works have focused on the actors' strategies and logics (Blanquart, et al., 2010; Chaplain, 1994; Cohou, 2000). For instance, Ribalaygua (2006) conducted a detailed analysis of enhancement strategies adopted to anticipate, support and promote the arrival of high-speed rail in small-sized Spanish cities. As Chaplain (1994) demonstrated in her PhD dissertation on the Channel Tunnel and the French Northern high-speed line, understanding of the behaviors and practices that accompanied the infrastructure project, from conception to completion, is essential to analyze territorial dynamics.

In accordance with these reflections and in the continuity of studies devoted to the influence of the choices of station location on the territorial integration of HSR (Bertolini, 1998; Loukaitou-Sideris et al., 2012; Mohino et al., 2014), our own previous research on HSR stations (Facchinetti-Mannone and Bavoux, 2010; Facchinetti-Mannone, 2012 and 2016) reveals that the process of territorialization of HSR has encountered a certain territorial inertia due as much to "the effects of place" as to the appropriation modes of the new transport supply by territorial actors. If, as Delaplace pointed out, "appropriation depends on factors such as station location and the strategy implemented by local 
stakeholders" (Delaplace, 2017), the degree of appropriation of the potentials of HSR has been a major factor in the involvement of local actors in the decision-making process leading to the choice of the location of HSR stations, and in the implementation of coherent and coordinated strategies improving the territorial integration of HSR. When local actors anticipate the opportunities offered by connection to the HSR network, not only do they actively work toward obtaining a station location in compliance with their territorial development projects, but they also implement measures to strengthen the territorial integration of the high-speed rail service (Facchinetti-Mannone, 2016). Focusing on the locations of stations, these analyses suggest the existence of different modes of appropriation which vary according to the degree of centrality of the railway stations, the mobilization of local actors confronted with the transport operators' supra-territorial logic and the temporal context of the HSR project implementation. These different elements result in highly diversified territorial dynamics which can only be highlighted by a thorough analysis of the HSR appropriation process.

\subsection{Appropriation: a multifaceted notion}

In geography, the concept of territory is used in conjunction with that of appropriation, a notion which is both many-sided and cross-disciplinary. According to the Online Dictionary "Trésor de la langue française" ${ }^{2}$, the term 'appropriation' refers to a dual process. First, the term 'appropriation' means "to adapt something to specific uses, needs or expectations". Secondly, it may be defined as the action of assigning oneself the ownership of something, taking possession of an object or a place, or acquiring experience or knowledge. It involves the exercise of a form of power, the preparation of a strategy and the construction of an identity.

This dual meaning and the numerous definitions of the notion of appropriation have led me to examine the scientific works dealing with the appropriation of public spaces and that of innovation from a heuristic perspective. My purpose here is to specify how the various disciplines which have studied these topics define and mobilize the concept in order to provide a theoretical and methodological framework to improve the comprehension of the appropriation process. A first review of the French scientific literature has revealed several common characteristics particularly fruitful to analyze the process of appropriation of high-speed rail. "Based on the confrontation of two potentialities: the potentiality of a world waiting to be appropriated and the capacity of the individual to appropriate objects and spaces in an identity quest" (Cova and Cova, 2001), appropriation is viewed as a dynamic process derived from complex systems of interdependence (Fischer, 2011) between the possessive, adaptive and identity dimensions of the notion.

By its possessive dimension, appropriation is first a conflictual process in which social actors are confronted with a certain number of constraints (Fischer, 2011) that they have to take into account and even to surpass. Analyzed from the angle of the power relationships expressed by struggles for the appropriation of places, from the territorial marking of individuals and groups or from the oppositions between the design logic and the user's logic (De Certeau, 1990; Perriault, 1989), this underlying conflictual dimension is an essential key to understanding the appropriation process of

\footnotetext{
${ }^{2}$ http://www.atilf.fr/tlfi
} 
high-speed rail. Although the strategies of appropriation adopted by the territorial actors in intermediate cities remain subject to the supra-territorial logics of transport operators, it has been shown that some territories have succeeded in reversing the logic prescribed by the railway operator to serve their own expectations, while others have not been able to derive the expected benefits although they have obtained rail service. Because these different "appropriative trajectories" vary according to the spatial and temporal contexts of the arrival of high-speed rail, they invite us to explore the actors' interactions occurring during the choices of station locations and the implementation of development strategies.

Beyond the diversity of topics and scientific fields, many research studies have also emphasized the dialogical dimension of the appropriation process which involves continuous, progressive and mutual adjustments (Orlikowski, 1996), according to a recursive logic (Brunel and Roux, 2006) between the adaptation of the subject and the modification of the object. As regards urban public places, Serfaty has shown that the user adjusts to the function of the place throughout his routine practices, which gradually change the sense of place (Korosek-Serfaty, 1988). Based on the Adaptive Structuration Theory developed by De Sanctis and Poole (1994) from Gidden's work (1987), this interactionist approach proves relevant to investigate the appropriation of high-speed rail stations and to understand the renewal of territorial structures in connection with the changes in the transportation system. Because it is gradually taking shape in the relation to its object (Jouet, 2000), appropriation plays a role in spatial structuration and the emergence of new territorial dynamics. These highly contingent territorial changes are the result of a process in which territorial actors interpret the changes introduced by the new transport supply, adapt them to their expectations and incorporate them into their practices, thus modifying the characteristics of the transport supply and the values that it conveys. In the course of interactions, this dual mechanism of adaptation affects the general territorial system, which in turn changes the functionalities of the new transportation supply and the actions and representations of local actors. These mutual adjustments explain the wide variety of territorial dynamics generated by projects initially designed according to the same logic.

Finally, appropriation constitutes an identity process. Social sciences have thus largely proved that the appropriation of objects, the assimilation of knowledge or the acquisition of experiences have contributed to shaping the identity of individuals. By extension, high-speed rail appears to be an "identity referent" (Brunel and Roux, 2006). Integration in the HSR network doubly contributes to the building of territorial identity. On the one hand, the improvements in accessibility and modernity conveyed by HSR (Delaplace, 2017; Harvey et al., 2014; Vickerman, 1997; Willingers et al., 2005) changes the relationship between the territory and the world at large, and increases its visibility on the national and European scales. This is evidenced in the renewal of the architecture of railway stations (De jong, 2009; Peters and Novy, 2012; Trip, 2008) or in the territorial marketing strategies and "flagship projects" (Peters, 2009) adopted by the cities and regions that have recently joined the "Club of HSR cities". On the other hand, high-speed rail changes the way local actors consider their territory; the new transportation supply becoming, through appropriation, a medium for territorial identity.

\subsection{A multi-pronged problematic approach to the appropriation of high-speed rail}


Addressing the issue of the territorialization process of HSR through the prism of appropriation offers the advantage of focusing the analysis on territorial actors. As pointed out by Ripoll and Veschambres, "reasoning in terms of appropriation has the major methodological and theoretical interest of emphasizing the spatial dimension of society, rather than the space itself, considered as something distinct, autonomous and external from society" (Ripoll and Veschambres, 2005). Among the numerous stakeholders involved in the territorialization process of the HSR stations, three categories of territorial actors have more particularly retained my attention (see figure 1): the railway users, the economic players and the local political and institutional actors.

Distinguished from each other by their practices, their relations to places and their expectations in terms of the new transportation supply, these three groups of actors have very different roles in the territorialization process of HSR. Although railway users and economic players have a limited decisionmaking power over HSR lines and the location of stations, their spatial distribution, characteristics and travel practices are widely taken into account during the negotiations concerning the location of stations and the definition of the railway service. Their travel practices and the ways they use HSR stations affect the profitability of HSR projects and are taken into consideration in the design, equipment and layout of these places. Lastly, the ways in which they integrate the station and the new transportation supply into their daily lives have spatial repercussions that influence the territorialization process of the new transportation system. The political and institutional sphere, which has more prerogatives than ever before to negotiate the location and rail service of the stations, has had an unequal influence depending on the geographical and temporal contexts of the implementation of the projects. Then, even if the location and services of the HSR station do not correspond to their expectations, these political actors have supported the accompanying strategies and territorial development plans set up to improve the territorial integration of the high-speed rail network.

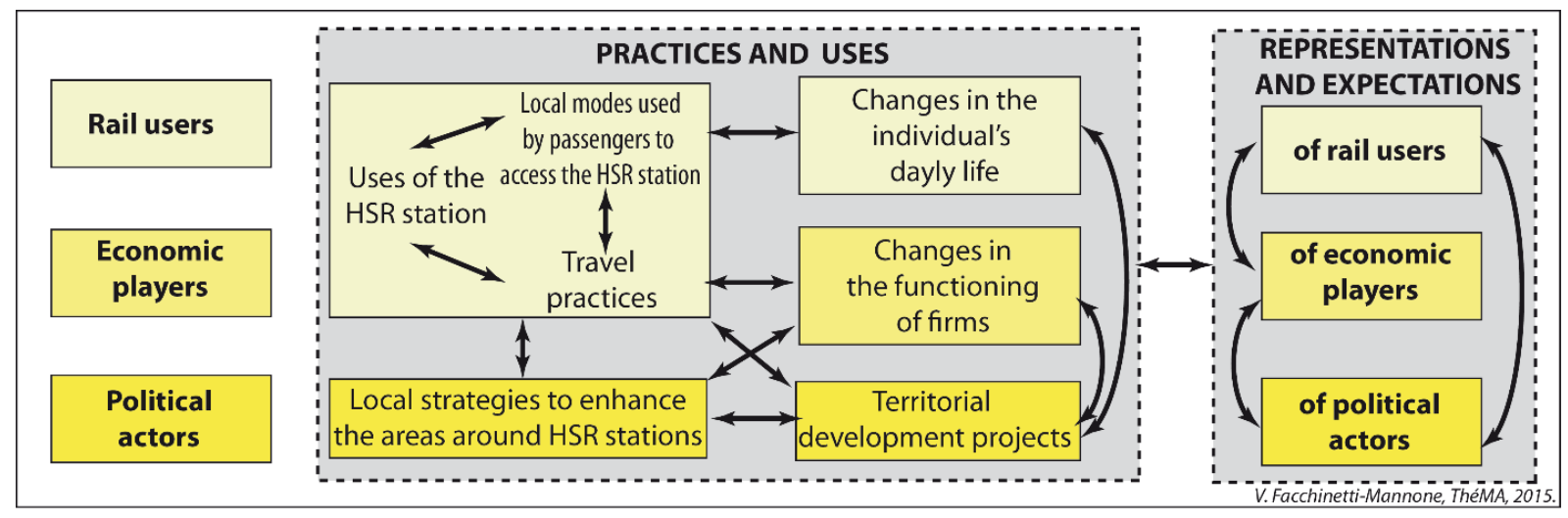

Figure 1 : The appropriation of HSR: a collective construction process

While the forms and mechanisms of appropriation differ according to the types of actors, they are nevertheless interdependent. Delaplace (2017) has pointed out that collective appropriation is a major issue in terms of the impact of HSR on served cities. Thus, after specifying how each local stakeholder has appropriated the renewal of the transport supply, it will be necessary to explore the relations that exist between these different modes of appropriation. This interactional approach revealing the actors' interactions involved in the territorialization of the infrastructure, considers 
appropriation as a collective construction process resulting from mutual adjustments between the various forms of appropriation that have been identified. Indeed, the strategies implemented by the political sphere to strengthen the territorial integration of railway stations weigh on the way in which passengers and economic players use HSR. These strategies also depend on the various forms of appropriation that have preceded or accompanied them, insofar as territorial planning takes into account (to a certain degree) the forms of appropriation revealed by companies' expectations and users' representations. Moreover, although figure 1 does not mention them explicitly, stakeholders who are negatively affected by HSR projects - such as land owners or residents who bear negative impacts and populations or regions whose accessibility has been reduced - should not be forgotten (they are included in the three categories). Indeed, their actions, representations and expectations can influence the actions and strategies developed by economic and political actors.

Appropriation appears in two ways: first through the strategies, practices and uses generated by the new transportation supply, and then through HSR representations and actors' expectations. Practices and behaviors, which refer to the real life experiences of territorial actors, are numerous. The appropriation of HSR can be analyzed through people's travel practices, in relation to their use of stations, and more generally by the way they integrate the new transportation supply into their daily lives or into the functioning of firms. By modifying commuting and travel patterns, HSR can influence household residential location choices (Diao et al., 2017; Chen and Haynes, 2015; Garmendia et al., 2008 and 2011), leisure habits (Bazin et al., 2011; Delaplace et. al, 2014), business location choices as well as labor organization in firms (Bazin et al., 2018; Facchinetti-Mannone, 2013; Willigers and Van Wee, 2011). Similarly, the strategies for enhancing the railroad sites and territorial projects linked to high-speed rail reveal the logic of appropriation supported by political and institutional actors (see Figure 1).

If indeed the various studies dedicated to appropriation have emphasized social players' actions, these acts cannot be separated from the representations that gave birth to them. Practices and representations are always linked (Gumuchian, 1991) and constitute two facets of a complex process that closely mingles collective representations, individual perceptions and response and adaptation mechanisms (Taddei and Staii, 2008). The representations created by the renewal of railway accessibility constitute an essential factor in understanding the practices and strategies that induce territorial changes in connection with the implementation of a new high-speed line. Thus, the analysis presented in this paper emphasizes the representations of the different territorial actors and describes the various interactions that bind them in order to confront these representations with the practices and strategies from which they are derived and that constantly change (see Figure 1).

Lastly, the analysis of HSR territorialization, in terms of appropriation, encourages researchers to highlight the temporal depth of the process. Indeed, appropriation is a long-term evolutionary process that starts well before the implementation of the new transport infrastructure and continues even after the trivialization of its uses (de Vaujany, 2003). Therefore, if the choice of location and the opening of stations are highlights in the territorialization processes insofar as they give a tangible reality to the HSR project, their appropriation starts taking shape from the first reflections on the emergence of the HSR line project. Later, appropriation gradually develops and changes during the various project implementation stages. It is thus fundamental to consider this diachronic dimension. On the one hand, it clarifies how the appropriation modes of the project have influenced the choice of 
the location of stations and the strategies developed to promote the territorial integration of HSR. On the other hand, it reveals how these strategies may modify the stakeholders' practices and representations in return. Thus, in order to take into account the dialogical and temporal dimensions of the process, this paper transposes of the analytical grid designed by Brunel and Roux (2006) in the field of marketing. This framework is particularly relevant for a dynamic perspective on the appropriation of HSR.

\section{A dynamic perspective on the appropriation of high-speed rail}

\section{1 - An approach adapted to the temporality of high-speed line projects}

Several authors have attempted to deconstruct the chronology of the appropriation process. Among them, Brunel and Roux (2006), inspired by Sartre's work on Desire and Possession, have constructed a comprehensive analytical grid of appropriative acts in the field of marketing (see Tab.1). Their study seeks to grasp the dialogical and conflictual relationship between demand and supply in order to understand how the purchase and the consumption of any product participate in the building of an individual's identity. In so doing, they have identified four strategies of appropriation (contamination, knowledge, creation and control) which appear in a specific way according to the different stages of the act of consumption.

\begin{tabular}{|l|c|c|c|c|}
\hline Pre-appropriation & Contamination & Knowledge & Creation & Control \\
\hline $\begin{array}{l}\text { Pre- acquisition } \\
\text { appropriation }\end{array}$ & Intrusion & Impregnation & Preconception & Will to vanquish \\
\hline $\begin{array}{l}\text { Appropriation during } \\
\text { acquisition }\end{array}$ & Transfer & $\begin{array}{c}\text { Researching } \\
\text { information }\end{array}$ & $\begin{array}{c}\text { Ressource } \\
\text { allocation }\end{array}$ & Takeover \\
\hline $\begin{array}{l}\text { Pre- Chonsumption } \\
\text { appropriation }\end{array}$ & Internalization & Discovery & Transformation & Possession \\
\hline $\begin{array}{l}\text { Appropriation during } \\
\text { consumption }\end{array}$ & Incorporation & Learning & Self-fulfillment & Domination \\
\hline $\begin{array}{l}\text { Post- consumption } \\
\text { appropriation }\end{array}$ & Passing on & $\begin{array}{c}\text { Dissemination / } \\
\text { Withholding }\end{array}$ & $\begin{array}{c}\text { Transformation of } \\
\text { self and society }\end{array}$ & Enjoyment \\
\hline
\end{tabular}

Source: based on.Brunel and Roux (2006).

Tableau 1 : Comprehensive analytical grid of appropriation

Their chronological approach is relevant in examining how the territorial appropriation of HSR changes over the three main stages of HSR projects (see figure 2):

- Over the two or three decades which elapse between the first evocations of an HSR project and the conclusion of its public debate, appropriation gradually builds up from the numerous and often contradictory representations which condition the territorial identification of the HSR project and the ability of local actors to collaborate and to implement development projects. During this gestation phase, numerous studies by the transport operator and the institutional and socio-economic actors help fuel the debate. Although at this stage nothing has been decided yet, mobilizations against or in favor of the infrastructure project, lobbying actions, technical and economic feasibility studies (now 
widely co-financed by local actors) and consultations organized in the public space generate a virtual reality of the project.

- Later on, projects get into an active elaboration phase that constitutes a turning-point in the spatial integration of the infrastructure. Reports and consultations preceding the Declaration of Public Utility (DUP) refine the technical and spatial characteristics of the project, evaluate its socio-economic and environmental impacts and consider its financing terms. Preliminary engineering studies and public inquiries gradually give substance to the HSR project, reducing the range of possibilities before the DUP initiates its concrete realization. From there, preliminary project studies, land acquisitions, financial negotiations, the construction site and the definition of railway services replace one another and materialize the "désir de gare" (desire for a rail station) (Troin, 2010). The new HSR station becomes a valuable potential resource and gives rise to anticipation strategies expressed through development projects and intense territorial marketing campaigns.

- The official opening of the HSR line marks the beginning of the operation phase that renews the forms of appropriation. During the first operating years, new travel practices accompany the adjustments in transport supply. Finally, with the gradual trivialization of HSR, the new mobility practices associated with the gain in accessibility go hand in hand with the slow implementation of the economic and urban projects linked to the HSR station and the territorial integration of the new transport supply.

During these three phases, appropriation evolves; the conflictual, dialogical and identity facets of the process become organized into different hierarchies according to the temporalities of each project and the specificities of each territory. The conflictual dimension, often predominant during the gestation of the project, is gradually replaced by the dialogic facet during its implementation, which in turn gives way to the identity dimension once the commissioning of the HSR line is completed. Nevertheless, these three components of appropriation occur to varying degrees of intensity depending on the geographical context.

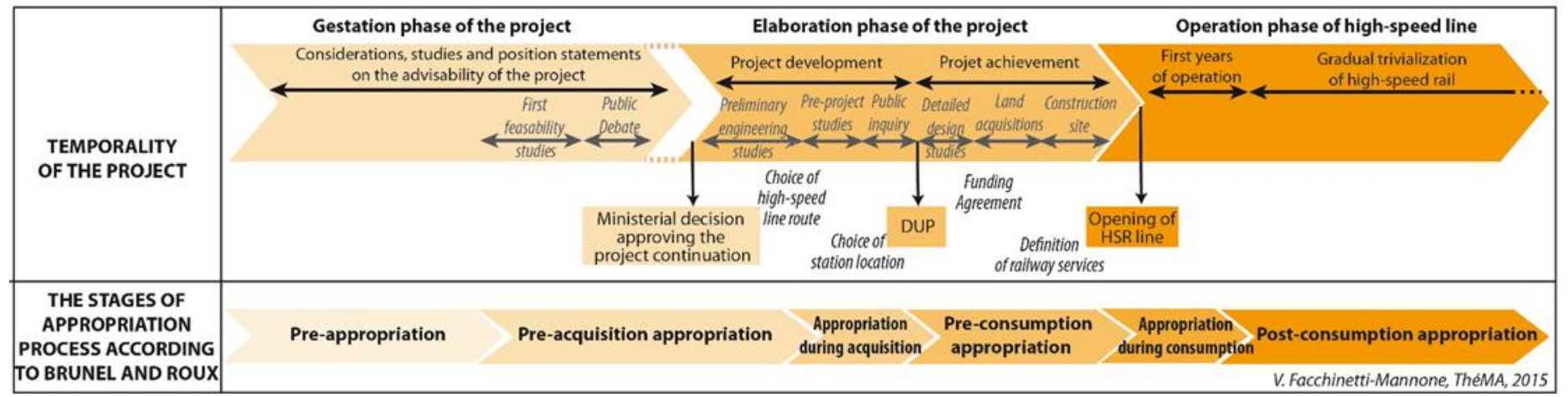

Figure 2 : Evolution of appropriation according to the different stages of the HSR project 


\section{2 - Evolution of the appropriation mechanisms of high-speed rail stations}

The analysis grid designed by Brunel and Roux (2006) emphasizes the recursive dimension of the process. Thus, the grid seems relevant in understanding how the appropriation of HSR develops (see fig. 2).

The initial evocations and the slow emergence of any HSR project correspond to a preappropriation phase when imagination construes reality and elaborates desire (Brunel and Roux, 2006). Faced with the possibility of HSR services, certain territorial actors inquire into the project and become imbued with it. They begin interpreting the potential renewal of accessibility that may be brought about by HSR, in various ways according to their expectations or fears. By means of a kind of symbolic deciphering (Brunel and Roux, 2006), pre-appropriation participates in the formalization of the desire for a railway station: territorial actors begin to consider the most favorable location for the station in order to realize their aspirations. During the slow maturation of the project, the multiplication of studies and consultations marks the gradual transition to the pre-acquisition appropriation stage that contributes to the recognition and identification of the Object of Desire (Brunel and Roux, 2006). Until the layout of the HSR line has been finalized, the successive studies which confront the project with the territorial specificities provide greater knowledge about the project. Appropriation takes the form of learning, thus contributing to the gradual identification of the project with the territory. The desire for an HSR station is transformed into a particular project, and HSR is gradually integrated into the territorial development project.

Established by the Bianco circular ${ }^{3}$, the public debate, which offers local actors the opportunity to express their opinions about the project imagined by the transport operator, is today a highlight of this pre-acquisition stage. The balances of power between proponents and opponents of the project and/or between competing territories, reflect the conflictual dimension of appropriation in a quest for a progressive coherence between local actors' expectations and the transport operator's logic. As the "Cours des Comptes" pointed out in a recent report (2014) devoted to high-speed rail, these initial consultations contribute to fixing the project into local reality, as revealed in the considerations on the strategies to be implemented to take advantage of the real or alleged opportunities of the arrival of high-speed rail which begin at this time.

From the choice of the HSR route to the Declaration of Public Utility, the technical and spatial characteristics of the project are defined in collaboration with the concerned stakeholders. During this phase, the nature of appropriation changes, drawing closer to the sequence of "appropriation during acquisition" that Brunel and Roux (2006) have defined as a phase of selecting the most convenient conditions for the realization of Desire. If the choices of the HSR route and location of stations reduce the scope of possibilities, they also give a symbolic weight to the project, which becomes identified with the served territory. During this stage, territorial agents negotiate with the infrastructure

3 The Bianco circular was adopted on December 15, 1992, after the protests against the Mediterranean high-speed line project (France). Enacted by the Transport Minister J.L Bianco, this governmental circular institutes a public debate in order to discuss the opportunities offered by the infrastructure very early in the decision-making process. 
operator the best conditions to give concrete expressions to their expectations and they conceive development strategies to convert the improvement of accessibility into attractiveness.

From the Declaration of Public Utility (DUP) to the completion of the infrastructure works, "preconsumption appropriation constitutes an intermediate stage during which the object is not yet consumed or incorporated, but prepared and integrated into a staging prior to its consumption" (Brunel and Roux, 2006). During this particularly active phase of mutual adjustments between representations and expectations, territorial actors take hold of the project and give it meaning by adopting the first accompanying measures, initiating the negotiations on HSR services and elaborating territorial marketing campaigns.

The opening of the HSR line marks the transition to the stage of appropriation while consuming or post-consumption appropriation. The expectations created among the different categories of actors by the new transportation supply are confronted to reality and lead to positive or negative evaluations (Brunel and Roux, 2006). This appropriation by use, which marks the gradual integration of the new transport supply into users' and economic actors' travel practices and territorial development strategies, indicates successive adjustments between the territory and the new transport system. Accompanying the trivialization of the new transport supply, post-consumption appropriation refers to what the territory finally retains from its experience according to the expectations created by the project. Becoming an integral part of the territorial identity, high-speed rail is, at this stage, integrated into territorial actors' everyday life, contributing, through the story-telling around the project, to the orientation of attitudes and beliefs in future situations of choice (Brunel and Roux, 2006).

Although the complete grid by Brunel and Roux (2006) was developed to analyze individuals' appropriation acts in a context of food consumption, it can easily be applied to the various stages of an HSR project to better understand the territorialization of stations. Its transposition nevertheless raises a few issues which require further clarification. Although HSR provides access to new destinations and alters the image of served territories, it is not an ordinary consumer product. It is thus necessary to re-examine the appropriative dimension of HSR stations in light of the relations that the various actors maintain with these places and the forms of territorial appropriation that they may generate. Transposing analytical methods designed to describe individual acts of appropriation to the questions posed by the territorialization of HSR also requires caution and circumspection. Indeed, even if individual appropriation remains a collective process (Taddei and Staii, 2008), territorial appropriation cannot be reduced to the aggregation of forms of individual appropriations but rather is constructed through the interactions of the appropriation logics of the various categories of actors.

\section{Methods of analysis of the territorial appropriation of high-speed rail}

\subsection{Reconstitution of the trajectories of high-speed rail appropriation}

The diachronic approach adopted in the proposed framework clarifies the progressive construction of appropriation during the different stages of the project. As the research devoted to the sociology of uses has emphasized (Chambat, 1994; Flichy, 1995; Jouet, 2000), new uses do not come out of nowhere but rather prolong previous practices, incorporating the reproduction of existing configurations into the progressive construction of new social or spatial structures. Thus, different 
methodological approaches, specific to each sequence previously identified, are suggested in what follows to comprehend the diversity of trajectories in the appropriation of the new transport supply (see figure 3).

- Focused on the political logics that prevail during the territorialization process of HSR, the first analysis suggests a geopolitical interpretation of actions, negotiations, compromises and possible conflicts that have led to the choice of the HSR line and the location of stations. It is necessary to identify the actors involved in the decision-making process according to their scale of intervention and their degree of mobilization. While the genesis of the project mainly involves political and institutional actors beside transport operators, the other categories of actors -through the associations and consular structures that represent them- are not absent from the debates. The analysis of their actions, in relation to the positions expressed and the arguments developed by each of them during the consultation phase, will clarify their respective roles in the decision-making process. The identification of the nature, the intensity and the evolution of the relationships established between the different stakeholders will help characterize the actors' interactions and specify their influence on the spatial integration of stations according to the geographical, historical and political contexts of the implementation of the HSR projects.

For each HSR project, the study collects several types of data in order to minimize the pitfalls associated with a retrospective reconstruction of facts and decisions that have marked out the different stages of the projects. Reports and studies produced during the preparation of the HSR project and press articles and interviews with the various actors involved in the choice of the location of stations facilitate a geopolitical re-reading of the actors' interactions during the territorialization process. The adopted approach also allows for the analysis of documentary resources produced during the consultations that punctuate the implementation of the project. The deliberations conducted by local authorities, the documents resulting from the public inquiries and the reports and working papers of the public debate provide rich research materials which have not been used up to now. For instance, the documents resulting from the public debate questioning the advisability of the HSR line ParisOrléans-Clermont-Ferrand-Lyon and of the qualitative study of the fears and expectations expressed in the contributions dedicated to the territorial development (Maréchal, 2014), revealed the diversity of the "pre-appropriation" and "pre-acquisition" logics aroused by the project according to actors' political and spatial affiliation.

- Centered on a systemic approach, the second analysis assesses the coherence and complementarity of the strategies and actions accompanying the project. This permits a reexamination of the co-constructed dimension of appropriation in connection with the exogenous dynamics that affect the functioning of the territorial system. In this second phase, appropriation evolves and takes specific forms according to the categories of actors. From the perspective of political and institutional actors, negotiations concerning the choice of rail services, the spatial planning intended to encourage the integration of stations and the strategies to promote and to enhance HSR shed light on the territorial appropriation of the new transport infrastructure. From the perspective of users and economic actors, the appropriation of the new transport supply appears at this stage in the way they adapt their travel practices to the changes introduced by HSR. The joint analysis of these different appropriative logics makes it possible to assess the coherence of the implemented development strategies by relating them to the appropriation forms that have accompanied the 
preparation of the HSR project. Research on the impacts of HSR in small-sized French and Spanish cities (Facchinetti-Mannone, et al., 2013) has highlighted the fact that the strategies developed to facilitate the expansion of new metropolitan functions near the HSR stations located on the outskirts of these cities corresponded neither to the expectations of companies (which, in their great majority, did not consider HSR as a factor in location) nor to the strengthening of the polarization of large cities revealed by railway customers' travel practices.

- Most French HSR lines in operation today offer the necessary perspective to analyze the "postconsumption appropriation" stage that occurs approximately 5 to 10 years after the inauguration of a high-speed line (Loukaitou-Sideris, 2013). The follow-up of valorization strategies and surveys conducted with railway travelers and companies will help to further understanding of the forms of appropriation that accompany the trivialization of the transport service. If the reorientations of development strategies highlight the evolution in appropriation logics, the follow-up of these strategies will be more specifically put into perspective by examining the ways in which the renewal of rail accessibility and the development projects created by HSR have been integrated into territorial projects. These projects are best apprehended via an analysis of the territorial coherence plans "Schéma de Cohérence Territoriale" (SCOT) ${ }^{4}$. The general and transversal nature of these planning documents, intended to reinforce the link between spatial planning and travel management policy, makes it possible to objectively apprehend the role devoted to HSR in the territorial project, the extent of integration of stations into territorial development strategies and the degree of their appropriation by institutional actors.

For instance, the comparison between the territorial coherence plans of the Pays Barrois (served by the Meuse TGV station) (Pays Barrois, 2014), Greater Besançon (served by the Besançon FrancheComté TGV station) (Syndicat Mixte du Schéma de Cohérence Territoriale, 2014) and Greater Rovaltain (served by the Valence TGV station) (Syndicat Mixte du SCOT du Grand Rovaltain-Ardèche-Drôme, 2014) underlines the very different roles played by HSR in each territorial project. Although these three territories are characterized by different demographic, economic and spatial developments, their HSR configurations have several similarities: new HSR stations built on the outskirts of cities, sharing of HSR services with the central station and valuation strategies based on the development of business parks near their peripheral stations. Despite a similar spatial distribution of train stations, the three territorial planning documents point out distinct modes of HSRappropriation by local political actors. HSR occupies a marginal place in the territorial project of the Pays Barrois, contrasting with the strong willingness to transform the new transport supply into a vector of European openness and economic development in Greater Besançon and with a ferment of coherence and territorial identity in the case of Rovaltain.

The modalities of appropriation identified through these planning documents need to be confronted with those of the other categories of actors, and more specifically with the ways in which railway users and economic players adapt the new transportation supply to their daily lives and functioning. Several business surveys (Bazin et al, 2016; Facchinetti-Mannone, 2013; Willigers and Van Wee, 2011) have revealed that HSR, whatever its uses and degree of influence in firms' location

\footnotetext{
${ }^{4}$ Territorial Coherence Plan established on the metropolitan/conurbation area scale.
} 
decisions, introduces a number of changes in their functioning. Some firms have taken advantage of the land available near the stations to gather together in a single place activities formerly scattered over several national or regional sites. Others have taken the opportunity offered by the improvement in accessibility to acquire new markets, expand their recruitment area or develop new economic partnerships. Beyond their spatial implications, these functional changes reflect specific forms of appropriation that need to be identified in order to better understand the diversity of territorial impacts of HSR.

The proposed approaches serve to analyze the co-construction of the appropriation process, from the emergence of the HSR project to the trivialization of its uses. Their aim is to reconstruct appropriative trajectories to identify, in the long run, the relations between these trajectories and the location and territorial integration of stations. Even if it is difficult to compare HSR projects designed at different times, this long-term follow-up reveals the specific influence of the decision-making context on the appropriation process, in relation to the spatial representations intrinsically linked to the travel practices and the uses of high-speed rail stations. Indeed, these places are invested with meanings and values (Peters and Novy, 2012; Willigers and Van Wee, 2011) that participate in their appropriation. This necessary confrontation between practices (concrete appropriation) and representations (abstract appropriation) involves an exploration of the imaginary dimension of stations in order to relate this image to the individual and collective strategies created by HSR.

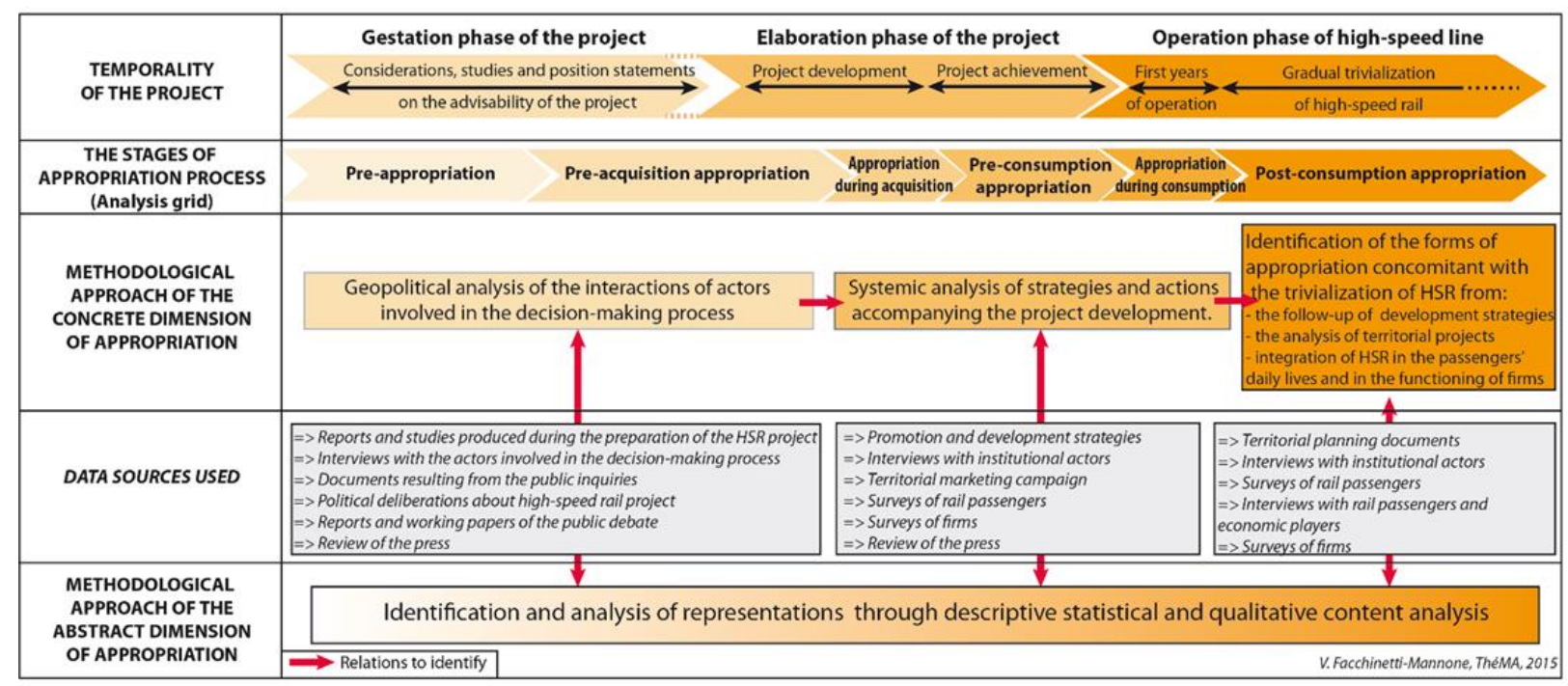

Figure 3 : Synthesis of the proposed methodological approach

\subsection{A semantic exploration of high-speed rail imaginary representations}

High-speed rail, synonymous with improved accessibility and a symbol of modernity, has largely enhanced the image of regions enjoying HSR services. Some vectors of this "image" effect may include the renewal of the architecture of railway stations (De jong, 2009; Peters and Novy, 201 ; Trip, 2008), the redevelopment of the station area and territorial marketing campaigns promoting the attractiveness of the newly-accessible destinations, and participate, each in its own way, to increasing 
the legibility and the reputation of the areas served by HSR (the image they give of themselves) and in the construction of a territorial identity (the image that they have of themselves).

Neglected for a long time by geographers, spatial representations (image) have become objects of research thanks to the influence of social geography. As Bailly and Ferras (1997) have pointed out, geography draws its richness from the analysis of a permanent mixture of real and imaginary. By analogy with the Image of the City studied by Lynch (1960) or Chalas (2003), the image of train stations refers to the representations they produce, the expectations and fears they feed, the values they convey and the myths they help to forge. By mixing perception of reality, social values and affective relationships with places, these representations fully participate in the production of space. In relation with the practices and strategies they influence, such representations are the key to how territorial actors appropriate space and transform it into territory.

Just like the material characteristics of spatial organization, these ideal representations, constructed from the way in which territorial actors perceive and interpret the changes introduced by high-speed rail, influence and guide individuals' daily practices and the policies implemented to facilitate the territorial integration of the new transport supply. The identification of the social values attached to HSR and the understanding of how these values have been constructed and sometimes exploited are thus essential in the analysis of spatial practices and implemented strategies.

In order to explore these representations, the speeches of the various actors involved in the project was submitted to a semantic analysis that mobilizes the tools and methods of content analysis. The different textual and oral sources gathered to study the spatial practices and strategies linked to the arrival of HSR constitute a relevant material to apprehend representations (see figure 3 ). The words used to describe a project or an object refer to a mental representation of the real object (Hernandez, 2003). They enlighten the understanding of spatial practices and the construction of the process of appropriation. Studied by means of a quantitative and qualitative approach, the transposition of HSR into words and pictures during the process reveals distinct forms of appropriation depending on the actors and the territories served. The challenge is then to identify how individual and collective representations affect spatial practices and to better understand the reciprocal influence that the different discourses have on each other throughout the duration of the appropriation process.

At this stage, the approach does not exclude any of the discourses or texts collected in connection with the reconstruction of the appropriative trajectories (see figure 3 ). These corpora, each in its own ways, make it possible to understand the expectations and fears created by HSR projects, the multiple representations attached to the location of HSR stations and the strategies used to develop railroad sites and the added values inherent in the improvement of accessibility. To decipher these language games, the different textual data will be subjected to a semiological and lexical analysis, mobilizing the tools and methods of content analysis (Bardin, 2013; Lebart and Salem, 1994; Maingueneau, 1987), that Berelson (1952) defined as "a research technique for the objective, systematic and quantitative description of the manifest content of communications, with the aim of interpreting them". First of all, it will be necessary to analyze the enunciative context of the textual data, not only to situate them in relation to the temporality of the HSR projects but also to clearly identify the elements that influence representations. Indeed, while some of the analyzed discourses are limited to a restricted circle, others, by virtue of their wide diffusion, contribute to the construction of social norms. This contextual study involves identifying the authors of the textual data and the 
people to whom they are addressed, specifying their sphere of influence, their spatial scale of intervention and their position in the decision-making process. This approach also defines the motivations of speeches that can take on very distinct tonalities depending on whether they meant to relate facts, to provide information, to explain a decision, to convince an audience or to promote a territory. Finally, the concomitant events associated with their enunciation must not be neglected insofar as they are likely to influence the individual and collective representations of the territorial actors.

Discourses and texts produced during the different phases of the HSR project need to be subjected to an initial quantitative lexicometry analysis. Based on the occurrence of the terms used, the frequency of co-occurrences, the relations established between the identified themes and the connotations attached to them, the analysis aims to obtain a first classification of the representation systems produced by high-speed rail. The representations identified by these statistical treatments will then constitute the subject of a more in-depth qualitative analysis, aimed at understanding the logics that have structured the representation systems, taking into account the contextual elements previously highlighted, the modalities of speech articulation, the allusive references and the stylistic registers.

For instance, the analysis of the image of HSR conveyed by various Territorial Coherence Plans confirms the differing roles of the new transport supply (see figure 4). HSR and the stations are mentioned only 13 times, usually laconically, in the SCOT of the Pays Barrois, in which the first mention of HSR, appearing very late compared to other SCOTs, refers to the noise pollution caused by the rail traffic. Presented in the very first pages of the territorial diagnosis, HSR is the subject of more numerous references in the presentation reports of Greater Besançon (28 references) and Greater Rovaltain (39 references), most often in the form of extensively argued paragraphs. A first quantitative analysis of the words associated with stations and HSR reveals distinct representations of the traditionally established link between railway accessibility and territorial attractiveness. Thus, while the SCOT of the Pays Barrois conveys a rather negative image of HSR, that of Greater Besançon highlights the link between a widely idealized European openness and the economic development of the urban area by means of numerous hyperboles. As for the SCOT of Greater Rovaltain, the HSR station and the economic activity zone to which it is systematically associated are presented as major vectors of European influence, development and territorial cohesion. 


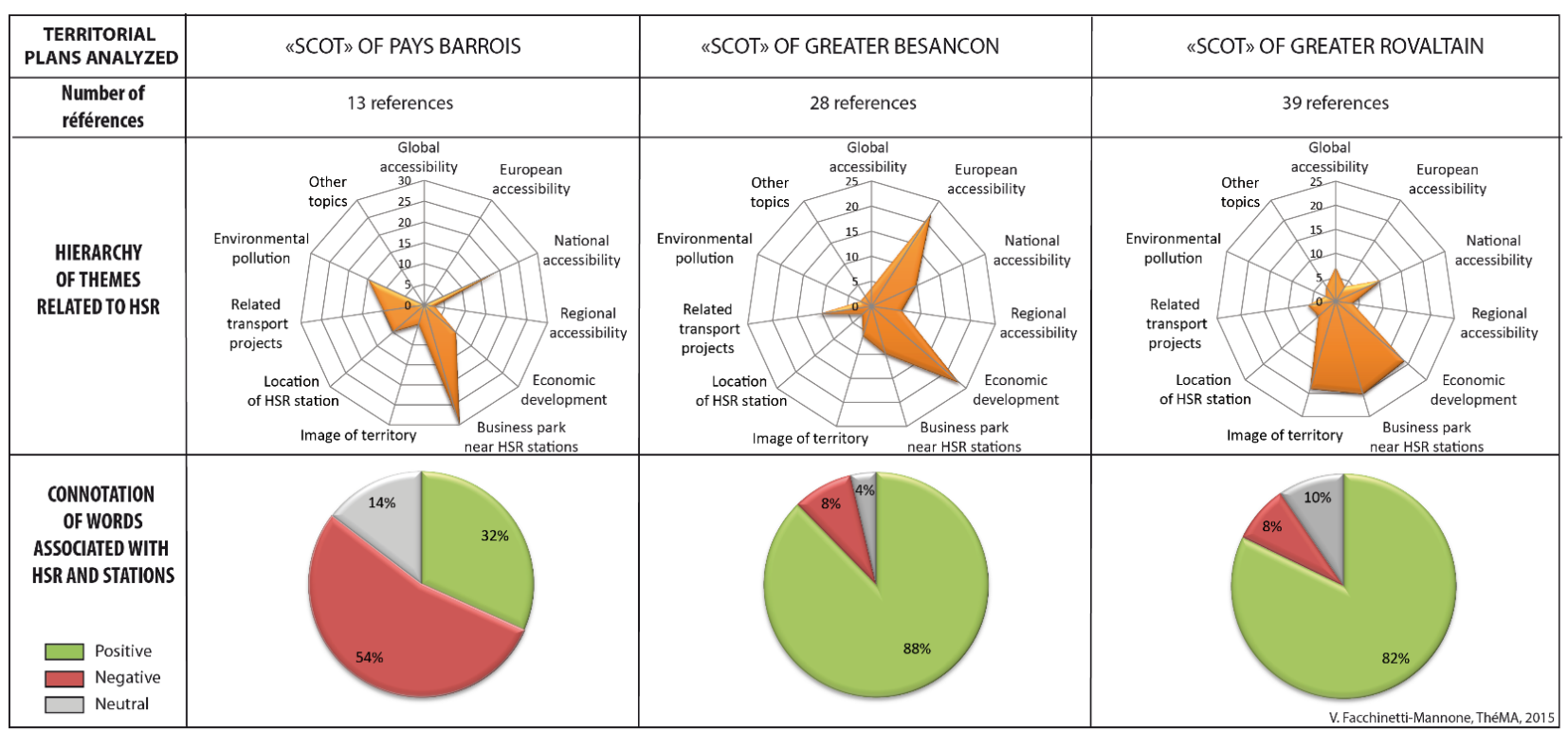

Figure 4 : Hierarchy and connotation of the words associated with high-speed rail

The joint analysis of the role devoted to HSR stations in the territorial project and that of their symbolic representations reveals the unequal appropriation of HSR by local actors. Beyond the specificities of the served regions, this unequal appropriation reflects the degree of involvement of local actors in the choice of the location of stations. When, as in Besançon or Valence (the main city of Greater Rovaltain), local actors played an active role in the negotiations leading up to the implementation of stations, the territorialization of high-speed rail is based on the adoption of development strategies that are largely integrated into the territorial project. It is also based on the construction of representations which exploit the mythical link between accessibility and attractiveness to further the achievement of this project. Reflecting institutional actors' expectations, these imaginary constructions play an essential role in the territorialization of high-speed rail because they influence the measures and policies adopted to enhance the spatial integration of stations. In the Pays Barrois where the appropriation of HSR is governed by an "intrusive logic", the SCOT describes the station as a foreign object, over-imposed on the territory, whereas the SCOT of Greater Rovaltain has made the new HSR station a real local symbol (Lussault, 2007) and a strong element of territorial identity at the service of its economic development.

\section{Conclusion}

As many scholars have pointed out (Bazin, et al. 2010; Delaplace, 2017; Feliu, 2012; LoukaitouSideris et al. 2012; Menerault, 1997 and 2000 Peters, 2009), the appropriation of HSR by local actors exercices a crucial influence in the great diversity of the impacts of HSR. Conceived as a collective construction process, this appropriation is derived from the mutual adjustments of strategies, behaviours and representations developed by the different categories of stakeholders involved in an HSR project (some may be primarily winners and other losers). However, up until now there has been 
no comprehensive method for analyzing the appropriation process of HSR in its collective, temporal and symbolic dimensions.

In focusing the analysis on the relations between the practices and representations of local actors involved in HSR projects, the challenge is to grasp the process of appropriation in its multiple components in order to understand the interactions between the location, the integration and the appropriation of HSR stations according to the various contexts of HSR projects implementations. Analyzing the mechanisms of HSR appropriation opens up new research perspectives that respond to a three-pronged problematic:

- firstly, the goal of improving understanding of the relations between the agents involved in the territorialization of the transport infrastructure by analyzing the interrelations between transport practices, the functioning of firms and development projects;

- secondly, the issue of observing the "image" effect linked to the individual and collective representations of high-speed rail;

- and lastly, the issue of examining the temporal dimension of the process.

By mobilizing various data and observation angles (see fig. 3), the methodological approach considered in this paper makes it possible to understand how spatial representations and practices feed each other and to specify the mutual influences of the appropriative logics of territorial actors during the successive stages of the territorialization process. Our initial exploratory analyses thus reveal the emergence of different forms of appropriation which emphasize that the territorialization of high-speed rail and HSR stations is ultimately the result of the overlapping of multiple territorialities which could be identified by the joint study of spatial practices and representations. By considering representations induced by high-speed rail, the present study sheds light on the interactions of actors involved in the territorialization of the new transport supply, integrating the symbolic and imaginary dimensions that guide spatial strategies and practices throughout the duration of the HSR project.

The exploration of the imaginary dimension of HSR stations from the representations conveyed by the discourses of the actors involved in their territorialisation is a useful complement to the reconstitution of appropriative trajectories. For instance, the comparison between the three planning documents studied in this paper has clearly shown how the representations and values attached to HSR have an influence on development strategies adopted to improve the territorial integration of HSR. As an extension of this work, a comparative analysis of the representations and values of HSR stations will help to clarify how this imaginary dimension contributes to the appropriation of highspeed rail. A dual comparison will be implemented. First of all, for each project, the comparison of the representations of different categories of actors will reveal how their mutual influence boosts the territorial appropriation of high-speed rail. Through their interactions, the various individual representations thus identified contribute to building a collective image of high-speed rail which, according to the principles of systemic thinking, is much more than the aggregation of the multitude of individual representations. Secondly, putting the different analyzed cases into perspective will allow us to interpret the spatial fluctuations of these representations in relation to the different choices of the location of stations and the measures implemented to enhance their integration. 


\section{References}

Adolphson, M. and Fröidh, O. (2017). Development of urban structure in proximity to new railway stations. RSA Annual Conference. Dublin.

Bailly, A. and Ferras, R. (1997). Eléments d’épistémologie de la Géographie. Paris: A. Colin.

Banister, D. and Lichfield, N. (1995). The key issues in transport and urban development. In D. Banister (ed.). Transport and urban development (pp. 1-16). London: E\&FN Spon.

Bardin, L. (2013). L'analyse de contenu. Paris: PUF, $2^{\text {nd }}$ ed.

Bazin, S., Beckerich, C. and Delaplace, M. (2010). Desserte ferroviaire à grande vitesse, activation des ressources spécifiques et développement du tourisme : le cas de l'agglomération rémoise. Belgeo, n¹-2, 66-77.

Bazin, S., Beckerich, C. and Delaplace, M. (2011). High-Seed Railway service innovation and business tourism development. In M. Samento and A. Matias (eds). Economics and Management of tourism: trends and recent developments (pp.115-141). Lisboa: Collecçao Manuiais, Universidade Luisiada Editora.

Bazin-Benoit, S., Beckerich, C. and Delaplace, M. (2016). High-Speed Rail, Corporate Estate and firm location in the central business district: the results from two surveys $(2008 ; 2014)$ in Reims. The Open transportation Journal, Vol.10, 7-21.

Bellet, C., Alonso, MP. and Gutierrez A. (2012). The high-speed rail in Spanish cities: urban integration and local strategies for socioeconomic development. In JM Urena (ed). Territorial implications of hHigh-Speed Rail: a Spanish perspective (pp. 163-196). Ashgate: Farnham.

Berelson, B. (1952). Content analysis in communication research. New York: Hafner Publ. Co.

Bertolini, L. (1996). Nodes and places: complexities of railway station redevelopment. European Planning Studies Vol.4 (3). 331-345.

Bertolini, L. (1998). Station area redevelopment in five European countries: an international perspective on a complex planning challenge. International Planning Studies Vol 3 (2). 163-184.

Bertolini, L. and Spit, T. (1998). Cities on rails: the redevelopment of railway station areas. London: E\&FN Spon.

Bertolini, L. (1999). Spatial development patterns and public transport: the application of an analytical model in the Netherlands. Planning Practice and Research Vol. 14 (2). 199-210.

Bertolini, L. (2008). Station areas as nodes and places in urban networks: an analytical tool and alternative development strategies. In F. Bruinsma (ed). Railway Development. Impacts on urban dynamics (pp. 35-57). Physica-Verlag HD.

Blanquart, C., Joignaux, G. and Vaillant, L. (2010). Infrastructure de transport et développement économique : quelles dynamiques d'appropriation par les acteurs productifs ? L'exemple de la filière céréalière autour du canal Seine - Nord Europe. Associazione Italiana di Scienze Regionali; Association de Science Régionale De Langue Française. Colloque de l'ASRDLF: Identité, Qualité et Compétitivité Territoriale - Développement économique et cohésion dans les territoires alpins, Sep 2010, Aoste, Italie. 17p

Brunel, O. and Roux, D.(2006). L'appropriation des produits par le consommateur: proposition d'une grille d'analyse. In: A. Grimand (ed), L'appropriation des outils de gestion. Vers de nouvelles perspectives théoriques ? Publications de l'Université de Saint-Etienne, 83-104.

Certeau De, M. (1990). L'invention du quotidien. Tome 1, arts de faire. Paris: Gallimard.

Chaplain, C. (1994). Des territoires à l'épreuve du Tunnel sous la Manche et du TGV Nord: les acteurs et leurs pratiques. Thèse de Doctorat de Géographie, Université Lumière Lyon 2, 293 p.

Chalas, Y. (2003). L'invention de la ville. Paris: Anthropos. 
Chambat, P. (1994). Usages des technologies de l'information et de la communication (TIC): évolution des problématiques. Technologies de l'Information et Société, Vol. 6 n³, 249-269.

Chen, Z. and Haynes KE. (2015). Impact of High-speed rail on housing values: an observation from the BeijingShanghai line. Journal of Transport Geography, Vol. 43. 91-100.

Cohou, M. (2000). Le destin d'une voie rapide : jeu d'acteurs, enjeu de développement. Toulouse: Presses Universitaires du Mirail.

Conticelli, E. (2011). Assessing the potential of railway station development in urban regeneration policies: an Italian case study. Procedia Engineering 21. 1096-1103.

Cours des Comptes (2014). La grande vitesse ferroviaire: un modèle porté au-delà de sa pertinence, Rapport de la Cours des Comptes, 173 p.

Cova, B. and Cova,V. (2001). Alternatives marketing. Paris: Dunod.

Delaplace, M., Pagliara, F., Perrin, J. and Mermet, S. (2014). Can high-speed rail foster the choice of destination for tourism purposes? Procedia Social and Behavioral Sciences Vol.111.166-175.

Delaplace, M. (2017). Assessing ex ante the wider effects of high-speed rail services in cities. The lessons drawn from a service innovation-based analysis. European review of Service Economics and Management $n^{\circ} 3.105-131$.

Diao, M., Zhu, Y. and Zhu, J. (2017). Intra-city access to inter-city transport nodes: the implications of high-speed rail station locations for the urban development of Chinese cities. Urban study Vol. 54 (issue10). 2249-2267.

Facchinetti-Mannone, V. (2009). Location of high-speed rail stations in French medium-sized cities and their mobility and territorial implications. International Conferences City Futures 09; Madrid, June 4-6, 2009.

Facchinetti-Mannone, V. and Bavoux, J.J. (2010). L'implantation des gares TGV en France: tensions interscalaires, jeux d'acteurs et recompositions spatiales. Belgeo, $n^{\circ} 1-2,9-22$.

Facchinetti-Mannone, V. (2012). Les gares TGV: des interfaces au service du projet urbain ? Revue Urbia $n^{\circ} 13$ «Interfaces et Métropoles », 27-47.

Facchinetti-Mannone, V. (2013). Les nouvelles gares TGV périphériques: des instruments au service du développement économique des territoires? Geotransports n²1-2. 51-66.

Facchinetti-Mannone, V., Bellet, C., Ribalaygua, C., and Richer, C. (2013). Les petites agglomérations françaises et espagnoles face à la grande vitesse ferroviaire: comment convertir l'accessibilité en attractivité. Les Cahiers Scientifiques du Transport, $n^{\circ} 63,3-31$.

Facchinetti-Mannone V. (2016). La territorialisation des gares de la grande vitesse. Habilitation à Diriger des Recherches, Dijon: Université de Bourgogne.

Facchinetti-Mannone, V., Carrouet, G. and Berion, P. (2016). Potentiel intermodal et pratiques de rabattement des voyageurs des gares TGV exurbanisées. In L. Chapelon (ed.).Transports et intermodalité. (pp.237-259). London: ISTE editions.

Feliu, J. (2012). High-speed rail in European medium sized cities: stakeholders and urban development. Journal of Urban Planning and Development, Vol 138 (issue 4)

Fischer, G.N. (2011). Psychologie sociale de l'environnement. Paris: Dunod, $2^{\text {nd }}$ ed.

Flichy, P. (1995). L'innovation technique. Récents développements en sciences sociales vers une nouvelle théorie de l'innovation. Paris: La Découverte.

Garmendia, M., Urena, JM., Ribalaygua, C., Leal, J., and Coronado, JM. (2008). Urban residential development in isolated small cities that are partially integrated in metropolitan areas by high-speed train. European Urban and Regional Studies vol. 15 (3). 249-264. 
Garmendia, M., Ribalaygua C. and Urena, JM. (2012). High Speed Rail implications for cities. Cities 29 (2), 26-31.

Garmendia, M., Romero, V., Urena, JM., Coronado, JM. and Vickerman, R. (2012). High-speed rail opportunities around metropolitan regions: the cases of Madrid and London. Journal of Infrastructure Systems Vol. 18 (4). $305-$ 313.

Giddens, A. (1987). La constitution de la société. Eléments de la théorie de la structuration. Paris: PUF.

Givoni, M. (2006). Development and impact of the modern high-speed train: a review. Transport reviews, Vol. 26 (5). 193-211.

Gumuchian, H. (1991). Représentations et aménagement du territoire. Paris: Anthropos.

Harvey, J., Thorpe, N., Caygill, M. and Namdeo, A. (2014). Public attitudes to and perceptions of high-speed rail in the UK. Transport policy 36. 70-78.

Hernandez, F. (2003). Le processus de planification des déplacements urbains entre projets techniques et modèles de ville. Thèse de doctorat en Aménagement de l'espace et urbanisme, Université d'Aix-Marseille III.

Jong De, M. (2009). European high-speed train station areas: the renaissance of the railway station. European Transport Conference.

Jouet, J. (2000). Retour critique sur la sociologie des usages. Réseaux Vol. 18 (100). 487-521.

Korosek-Serfaty, P. (1988). La sociabilité publique et ses territoires. Places et espaces publics urbains. Architecture \& Comportement Vol. 4, $\mathrm{n}^{\circ} 2$, pp. 111-132.

Lebart, L. and Salem, A. (1994). Statistique textuelle. Paris: Dunod.

Loukaitou-Sideris, A., Cuff; D., Higgins, T. and Linovsky, O. (2012). Impact of high-speed rail stations on local development: a Delphy Survey. Built Environment vol. 38 (1). 51-70

Loukaitou-Sideris, A. (2013). New rail hubs along high-speed rail corridor in California: urban design challenges. Transportation research record: Journal of the transportation research board, Vol 2350. 1-8.

Loukaitou-Sideris, A. and Peters, D. (2015). High-speed rail stations as transportation nodes and places: lessons for California. Washington: Transportation Research Board 95th Annual Meeting.

Lussault, M. (2007). L’homme spatial. La construction sociale de l'espace humain. Paris: Editions du Seuil.

Lynch, K. (1960). The image of the city. Cambridge: The MIT Press.

Maingueneau, D. (1987). Nouvelles tendances en analyse du discours. Paris: Hachette.

Marechal, C. (2014). Le débat public du projet de LGV Paris-Orléans-Clermont-Lyon. Analyse des cahiers d'acteurs, Mémoire de Master 1 sous la direction de V. Facchinetti-Mannone, Dijon: Département de Géographie, Université de Bourgogne, 93 p.

Martinez Sanchez-Mateos, H. and Givoni, M. (2012). The accessibility impact of a new high-speed rail line in the UK - a preliminary analysis of winners and losers. Journal of Transport Geography 25. 105-114.

Menerault, P. (1996). Le TGV Nord : appropriation locale d'un grand projet, INRETS.

Menerault, P. (1997). Processus de territorialisation de la grande vitesse ferroviaire: le TGV et les régions : le cas du Nord-Pas de Calais, INRETS.

Menerault, P. (2000). Appropriation régionale de la grande vitesse ferroviaire et rôle des régions dans la dynamique des réseaux: le cas du TGV en Wallonie et en Bretagne, Rapport INRETS-TRACES.

Menerault, P., Urena, JM. and Garmendia, M. (2009). The high-speed rail challenge for big intermediate cities: a national, regional and local perspective. Cities Vol. 26 (5). 266-279. 
Mohino, I., Loukaitou-Sideris A. and Urena, J.M. (2014). Impacts of High-speed rail on metropolitan integration: an examination of London, Madrid and Paris. International Planning Studies Vol. 19 (3-4), 306-334.

Orlikowski, W.J. (1996).Improvising organizational transformation over time: a situated change perspective. Information Systems Research, vol. 7 (1). 63-92.

Pays Barrois, (2014). Schéma de Cohérence Territoriale du Pays barrois. Rapport de présentation.

Pays Barrois, (2014). Schéma de Cohérence Territoriale du Pays barrois. Projet d'Aménagement et de Développement Durable, $52 \mathrm{p}$.

Pays Barrois, (2014). Schéma de Cohérence Territoriale du Pays barrois. Document d'Orientations et d'Objectifs, $110 \mathrm{p}$.

Perriault, J. (1989). La logique de l'usage. Essai sur les machines à communiquer. Paris: L'harmattan.

Peters, D. (2009). The renaissance of inner-city rail station areas as a key element in contemporary urban restructuring dynamics. Critical Planning Vol. 15 (1).162-185.

Peters, D. and Novy, J. (2012). Rail station Mega projects: overlooked centrepieces in the complex puzzle of urban restructuring in Europe. Built Environment Vol. 38 (1). 5-11.

Plassard, F. (2003). Transport et territoire. Paris: La documentation française.

Ribalaygua, C. (2006). Nuevas estaciones perifericas de alta velocidad ferroviaria: estrategias para su incorporacion a las ciudades espanolas. Ciudad Real: Universidad de Castilla-La Mancha, E.T.S. de Ingenieros de Caminos, Canales y Puertos.

Ripoll, F. and Veschambres, V. (2005). L'appropriation de l'espace comme problématique. Norois $195, \mathrm{n}^{\circ} 2$, pp. 7-15.

Sanctis De, G. and Poole, M.S. (1994). Capturing the complexity in advanced technology use: adaptative structuration theory. Organization Science, Vol. 5 (2),121-147.

Syndicat Mixte du Schéma de Cohérence Territoriale, (2014). Schéma de Cohérence territoriale de l'agglomération bisontine. Rapport de présentation. Besançon: AUDAB.

Syndicat Mixte du Schéma de Cohérence Territoriale, (2014).Schéma de Cohérence territoriale de l'agglomération bisontine. Projet d'Aménagement et de Développement Durable Besançon: AUDAB.

Syndicat Mixte du Schéma de Cohérence Territoriale, (2014). Schéma de Cohérence territoriale de l'agglomération bisontine. Document d'Orientations Générales. Besançon: AUDAB.

Syndicat Mixte du SCOT du Grand Rovaltain-Ardèche-Drome, (2014), Schéma de Cohérence territoriale du Grand Rovaltain. Rapport de présentation.

Syndicat Mixte du SCOT du Grand Rovaltain-Ardèche-Drome, (2014). Schéma de Cohérence territoriale du Grand Rovaltain. Projet d'Aménagement et de Développement Durable, 76 p.

Syndicat Mixte du SCOT du Grand Rovaltain-Ardèche-Drome, (2014). Schéma de Cohérence territoriale du Grand Rovaltain. Document d'Orientations et d'Objectifs, $124 \mathrm{p}$.

Taddei, R. and Staii, A. (2008). Pour une grille d'analyse de l'appropriation: du cadre conceptuel élargi à l'opérationnalisation empirique. Communication à la $13^{\text {ème }}$ conférence de l'AIM, Université Dauphine, 8 p.

Tapiador, FJ., Burchhart, K. and Marti-Henneberg, J. (2009). Characterizing European high-speed train stations using intermodal time and entropy metrics. Transportation Research Vol. 43 (2). 197-208.

Trip, JJ. (2008). Urban quality in high-speed train station area redevelopment: the cases of Amsterdam Zuidas and Rotterdam Centraal. Planning Practice \& Research, Vol 23 (3). 383-401. 
Troin, J.F. (2010). Désirs de gares TGV: du projet des édiles locaux au désaménagement du territoire. Belgeo n¹2, pp. 23-34.

Urena, JM., Ribalaygua, C., Coronado, JM., Escobedo, F. and Garmendia, M. (2006). Situaciones y retos territoriales de la alta velocidad ferroviaria en España. Ciudad y Territorio XXXVIII.397-424.

Urena, JM., Coronado, JM., Garmendia, M. and Romero, V. (2012). Territorial implications at national and regional scales of high-speed rail. In JM. Urena (ed) .Territorial implications of high-speed rail: a Spanish perspective (pp. 129-161). Ashgate: Farnham.

Vaujany De F.X. (2003). Les figures de la gestion du changement sociotechnique. Sociologie du Travail, vol. 45, 515-536.

Vickerman, R. (1997). High-speed rail in Europe experience and issues for future development. Annals of Regional Science, Vol. 31 (1).21-38.

Vickerman, R. (2015). High-speed rail and regional development: the case of intermediate stations. Journal of Transport Geography Vol. 42. 157-165.

Willigers, J., Floor, H. and Van Wee, B. (2005). High-speed rail's impact on the location of office employment within the Dutch Randstad Area. 45th congress of the European regional science association, Amsterdam. 23-27.

Willigers, J. and Van Wee, B. (2011). High-speed rail and office location choices. A stated choice experiment for the Netherlands. Journal of Transport Geography 19. 745-754. 